\title{
Effects of Higher Order Questioning in Prekindergarten for School Readiness
}

\author{
Dr. Tiffany Papa ${ }^{1}$ \\ ${ }^{1}$ Teacher Education Department, Nicholls State University, Thibodaux, Louisiana, USA \\ Correspondence: Dr. Tiffany Papa, CEBS Associate Professor, BFED Advisor/Early Childhood Education \\ Master's Program Chair, Nicholls State University, Thibodaux, Louisiana, USA.
}

Received: May 1, 2020 Accepted: May 26, 2020 Online Published: June 10, 2020

doi:10.5539/jedp.v10n2p25 URL: http://doi.org/10.5539/jedp.v10n2p25

\begin{abstract}
This study investigated whether the strategy of higher order questioning during interest area time would have a positive effect on kindergarten school readiness (specifically focusing on mathematical and language concepts) for students in a low-socioeconomic area school. Evidence from the Developmental Indicators for the Assessment of Learning/ Third Edition (DIAL-3) scores (completed upon entering kindergarten) establishes that the students in this low-socioeconomic area school were not kindergarten ready.

Statistical analyses concurred that increasing the frequency of higher order questioning during interest area time significantly improves the test performance of students within the mathematical and language concepts area of the DIAL-3 assessment.

The student achievement results of providing teacher training in higher-order questioning techniques during interest area time (the most vital learning time of the prekindergarten day) has provided evidence of increased cognitive development, ultimately increasing student achievement in mathematical and language skills. High-quality prekindergarten services involving best practices are the precursors for kindergarten; therefore, improving teacher-child verbal interactions in prekindergarten ultimately addresses the issue of kindergarten school readiness.

Additional findings included a correlation indicating that the students who did well in Language skills also did well in Mathematics and a statistically significant correlation existed between better scores and positive behavior.

It is anticipated that the contributions of the present study will encourage future research that will continue to elaborate upon the effects of higher order questioning at the prekindergarten level on kindergarten school readiness.
\end{abstract}

Keywords: early childhood education; higher order questioning; prekindergarten; interest area time; early educational experiences

\section{Introduction}

Prekindergarten students do not exhibit the skills necessary in mathematical concepts and language concepts for kindergarten school readiness. This study investigated whether the strategy of higher order questioning during interest area time would have a positive effect on kindergarten school readiness (specifically focusing on mathematical and language concepts) for students in a low-socioeconomic area school. Evidence from the Developmental Indicators for the Assessment of Learning/ Third Edition (DIAL-3) scores (completed upon entering kindergarten) establishes that the students in this low-socioeconomic area school were not kindergarten ready.

\subsection{Background and Significance of the Problem}

Factors that may be attributed to the lack of school readiness are as follows: (1) the socioeconomic status of the children; (2) the sparsity of prekindergarten services for children statewide; and (3) with regard to the children who are afforded these services, the lack of the implementation of best practices in the prekindergarten setting specifically teacher-child verbal interactions throughout the prekindergarten school day.

With regard to the first factor, researchers examining student performance consistently find that one of the most important influences on student achievement is the socioeconomic status of students. The more affluent the student's background, the better he or she will perform (Tajalli \& Opheim, 2005). The target school chosen for this study is located within a low socioeconomic area with a high percentage of families qualifying for the free or 
reduced lunch program within the local school district. The above-mentioned research concurs with the status of DIAL-3 scores upon kindergarten entrance within the local school district. According to the Title One Coordinator of the local school district, a significant proportion of the scores in the mathematical concepts subsection of the DIAL-3 demonstrated that the children within the target school scored low in the areas of positioning, shapes, counting and concepts such as biggest, longest, shortest and least. In the language subsection of the DIAL-3, a significant proportion of the scores demonstrated that the children within the targeted school scored low in the areas of articulation, letters and sounds problem solving and sentence length (personal communication, May 16, 2007).

With regard to the sparsity of prekindergarten services for children statewide, in 1995 , following a logical progression in expanding preschool programs, the state of Georgia created and implemented statewide universal prekindergarten to include not only the at-risk population but also all preschool aged children in the state. After Georgia's expansion, the state of Oklahoma followed suit. Additionally, New York and West Virginia are currently in the process of phasing in statewide universal prekindergarten, with completion of the expansion expected by the year 2012 (Barnett, Hustedt, Robin \& Schulman, 2004, p.98). Although Louisiana makes significant contributions to prekindergarten through four funding initiatives, it is still unable to provide a free education to all 3 to 5 -year-old children in the state.

In addressing factor three, uninformed teachers contribute significantly to the nature of the problem. Although, prekindergarten teachers are currently becoming highly qualified in their field, the professional growth opportunities for improvement in prekindergarten strategies and training in teacher-child engagement is lacking. Dr. Robert Pianta, a National Center for Early Development and Learning (NCEDL) researcher at the University of Virginia stated that prekindergarten teachers do not typically engage in focused instruction that uses a variety of strategies to engage children, nor do they have extended discussions that encourage children to problem solve and extend verbal expression. Noteworthy is the fact that superficial task demands, such as giving directions and routine tasks predominate over skill building and teacher-child verbal engagement (Bryant, Clifford, Early \& Little, 2005). The NCEDL conducted a multi-state study of prekindergarten classrooms in 2001 and the findings indicate that classroom quality in the participating six states was lower than research has indicated is best for children, especially with regard to instruction. The study implicated that uninformed teachers do not utilize best practices in most of the prekindergarten classrooms that were observed (Bryant et al., 2005). Classroom observations within this study indicated that children's interactions with teachers were minimal and when interactions did occur, they were not at a level that would help the children gain more complex understandings of language and mathematical concepts. Children were involved with a teacher or other adult in less than one-third of the observations, especially during interest area time and routines. When teachers and children were interacting, minimal interaction was observed and the interactions usually took place during whole group time (Bryant et al., 2005). This small proportion of time in which children do interact with the teacher is in contrast to the growing research that suggests that learning is most likely to occur when children engage in pre-academic material with an adult who involves them in responsive, elaborate interaction (Bryant et al., 2005).

According to the Region Three Coordinator (personal communication, January 15, 2007) of the local school district, most of the prekindergarten classrooms are similar in their practices to classrooms in the above-mentioned study. In these classrooms, prekindergarten teachers do not use best practices and do not engage children in elaborate verbal interactions during the most vital segments of the prekindergarten day and therefore do not meet the needs of young children.

The problem of school readiness involves several issues, one of which may be the implementation of teacher training beyond formal education for prekindergarten educators. In 2002-2003, 142 (58\%) of prekindergarten teachers in the Austin Independent School District in Texas attended professional development training directly related to prekindergarten instruction. Ninety-four percent of the teachers responding to the teacher survey conducted within this study agreed or strongly agreed that the training they received was beneficial to their understanding of learning strategies for prekindergarten students (Curry, 2003).

The National Association for the Education of Young Children (NAEYC) encourages utilizing best practices in early childhood education settings (Epstein, 2007). Teacher training in best practices can involve various methods. One strategy includes educators taking conversational turns with students, which allows the students to formulate and express their thoughts. Educators asking higher-order and open-ended questions within these deliberate conversations challenges their cognitive abilities (Epstein, 2007).

According to Epstein, "Young children need to be exposed to a rich and varied vocabulary" and this can be accomplished by deliberately creating conversations involving questioning which encourages critical thinking (Epstein, 2007). Providing training in higher order questioning techniques during interest area time (the most vital learning time of the prekindergarten day), is expected to increase cognitive development, ultimately increasing 
student achievement in mathematical and language skills. According to the National Association for the Education of Young Children (1997), interest area time is considered vital to the early childhood curriculum because developmentally appropriate programs encourage children's active exploration of their natural environment with children manipulating concrete objects and learning through hands-on direct experiences (Bredekamp \& Copple, 1997). High-quality prekindergarten services involving best practices are the precursors for kindergarten; therefore, improving teacher-child verbal interactions in prekindergarten would ultimately address the issue of kindergarten school readiness.

Best practices include the use of higher order questioning to stimulate brain development in all areas, and in particular, mathematical and language concepts (Gellens, 2000). Higher order questioning is teacher questioning that requires a higher level of cognitive functioning when students are engaged in evaluating information (Wimer et al., 2001). According to the Region Three Coordinator (personal communication, January 15, 2007) of the local school district, higher order questioning is not being implemented during the most important part of the prekindergarten day in the target school. The purpose of this study was to determine whether the implementation of higher order questioning during interest area time would affect kindergarten readiness in the areas of mathematical concepts and language concepts.

The setting for this study included three prekindergarten classrooms within an elementary school within the local school district. The local region is a semi-suburban area composed of many small communities that are economically challenged. The mission statement of the local school district is to offer exemplary academic, vocational, and co-curricular programs and to develop students' sense of responsibility, citizenship, and respect for others (Lafourche Parish School Board, 2007). The vision statement is that education is a shared responsibility of the schools, students, families, school system staff, school board, local government agencies, higher education and the business community. These stakeholders are committed to helping all students to become lifelong learners, realize their full potential, and appreciate the relevance of their education toward lifetime success (Lafourche Parish School Board, 2007).

As a stakeholder and an advocate for young children, the researcher shares in the responsibility of educating prekindergarten students to the extent of their full potential. Therefore, the researcher anticipates that the results from this study will contribute to the body of knowledge necessary to ascertain positive changes in the area of preschool education and ultimately kindergarten school readiness

Three prekindergarten classrooms within a low-socioeconomic area school were selected for this study. The purpose of the study was to determine the effects of prekindergarten higher order questioning on kindergarten school readiness. The target school was considered a medium performance school within the local school district, according to the Developmental Indicators for the Assessment of Learning/ Third Edition (DIAL-3) scores. This standardized test is administered at the prekindergarten level and the kindergarten level at all elementary schools within the district.

The target school contained the largest student population of the 13 elementary schools within the school district with 113 students. In the target school, almost $64 \%$ of the students receive free or reduced lunches. Students qualify for the free or reduced lunch program by meeting the district criteria for low family income, thereby granting free or reduced fees for student lunch services. Over $59 \%$ of the students in the target school scored in the $1^{\text {st }}$ or $2^{\text {nd }}$ quartile on the DIAL-3 assessment, thus scoring below the accepted standard. By selecting the most populated elementary school in the district, more prekindergarten services are available for research. For organizational purposes, the following table was created by the researcher to provide a clear picture of the need to improve the achievement of the students within the target school. 
Table 1. Table of Target School Relevance to Study

\begin{tabular}{|c|c|c|c|c|c|c|c|c|}
\hline Name of School & \multicolumn{2}{|c|}{$\begin{array}{l}\text { Total Percent of } \\
\text { performance in } \\
\text { 1st \& 2nd } \\
\text { quartile }\end{array}$} & School & Size & & School & SEI & $\begin{array}{l}\text { Percentage on } \\
\text { Free \& } \\
\text { Reduced } \\
\text { Lunch (2007) }\end{array}$ \\
\hline School 1 & 10.00 & Least Need & School 1 & 26 & Least Students & School 1 & $44.03 \%$ & Least \\
\hline School 2 & 42.42 & & School 2 & 30 & & School 2 & $44.47 \%$ & \\
\hline School 3 & 48.08 & & School 3 & 52 & & School 3 & $56.02 \%$ & \\
\hline School 4 & 50.00 & & School 4 & 52 & & School 4 & $57.34 \%$ & \\
\hline School 5 & 52.38 & & School 5 & 66 & & School 5 & $57.46 \%$ & \\
\hline School 6 & 53.85 & & School 6 & 70 & & School 6 & $57.56 \%$ & \\
\hline School 7 & 56.52 & & School 7 & 76 & & School 7 & $57.95 \%$ & \\
\hline TARGET SCHOOL & 59.29 & & School 8 & 81 & & TARGET SCHOOL & $63.59 \%$ & \\
\hline School 9 & 74.07 & & School 9 & 84 & & School 9 & $67.14 \%$ & \\
\hline School 10 & 74.29 & & School 10 & 92 & & School 10 & $73.57 \%$ & \\
\hline School 11 & 77.27 & & School 11 & 105 & & School 11 & $75.00 \%$ & \\
\hline School 12 & 86.84 & & School 12 & 110 & & School 12 & $77.54 \%$ & \\
\hline School 13 & 110.95 & Greatest Need & TARGET SCHOOL & 113 & Most Students & School 13 & $80.45 \%$ & Most \\
\hline
\end{tabular}


The table shown on the previous page (See Figure 1) contains the three variables that provide evidence of the relevance of the target school to this study. The table includes all 13 elementary schools within the local school district. The data were aggregated in percentages and ranked according to school performance indicated by the DIAL-3 (kindergarten entry) scores of each school from the least need (highest scores) to the greatest need (lowest scores). The data were also delineated by the size of the school (student population) and the socioeconomic income of the area in which the school is located. Income data were collected by totaling the number of Free or Reduced Lunch Program recipients within each elementary school (ranked from lowest to highest participation status). Students qualify for the Free or Reduced Lunch Program by meeting the district criteria for low family income, thereby granting Free or Reduced fees for student lunch services. The target school is indicated in bold type and provides evidence of middle school performance $\left(1^{\text {st }}\right.$ column), the large school size (student population $-2^{\text {nd }}$ column), and the socioeconomic standing (according to Free and Reduced Lunch Program participation) as compared to other elementary schools within the local school district $\left(3^{\text {rd }}\right.$ column $)$. This table provides documented evidence to support the selection of the school in which this study was implemented.

\subsection{Purpose of the Study}

The purpose of this study was to identify whether the strategy of higher order questioning during interest area time had a positive effect on kindergarten school readiness (specifically focusing on mathematical and language concepts) for students in a low-economic area school. Evidence from the Developmental Indicators for the Assessment of Learning/ Third Edition (DIAL-3) scores (completed upon entering kindergarten) established that the students in this low-economic area school were not kindergarten ready.

The researcher implemented the strategy of higher order questioning during interest area time in three prekindergarten classrooms within a low-socioeconomic area school. Specifically, the researcher worked with the students in each classroom one day per week for two hours (interest area time). The teachers/paraprofessionals continued this process throughout the remaining four school days. Working with the prekindergarten students involved the researcher entering each interest area within each classroom and addressing each student individually with higher order questions relating to the materials within the specified area. When the researcher addressed the students within the block area, an example of the questions that were asked were "What are you making with the blocks?" and "How could you make a house with these blocks?" The researcher extended the students' answers to these questions by asking additional questions that encouraged the students' to critically think and apply skills such as evaluation and analysis to their knowledge base. Additionally, the researcher provided training by modeling this type of questioning for teachers and paraprofessionals in order to assure that this was implemented continuously at interest area time each day during a three-month period.

One of the components of best practices in early childhood education is interacting with children (Epstein, 2007). The prekindergarten setting provides numerous opportunities for interacting with young children, one of which is encouraging and supporting language and communication. Teachers can support children's language development with many different strategies. These strategies include taking conversational turns with them, observing and listening while they take time to formulate and express their thoughts, and asking higher-order and open-ended questions to challenge them and allow them to respond in conversation (Epstein, 2007). According to Epstein, "Young children need to be exposed to a rich and varied vocabulary and the rules of discourse in order to develop the language facility that underlies the later acquisition of literacy, interpersonal problem-solving skills, and other cognitive and social abilities" (p.15). Providing children with interesting materials and experiences they want to talk about is an excellent method of promoting language development. Additionally, teachers should establish a climate in which children feel free to talk with one another and to be sure they themselves converse with all of the children, including those who are quiet or whose demeanor makes conversation difficult (Epstein, 2007). "These strategies will increase the amount and complexity of children's language and create a classroom in which lively conversations accompany busy hands and minds" (Epstein, 2007, p.15).

Teachers can support children's language development by implementing higher order questioning during interest area time in prekindergarten classrooms. Interest areas or learning centers are the primary setting in which children learn. Interest areas make up the physical environment of the prekindergarten classroom. According to the Creative Curriculum for Preschool, the physical space divided into interest areas is an ideal setting for preschool children. Separate interest areas with varied materials offer children a range of clear choices for play and active engagement (Dodge, Colker, Heroman, 2002). As long ago as the nineteenth century, Froebel identified the value of play because of the opportunities it provides for sensory experiences which are the foundation of intellectual development. Parallel to Froebal's theory, in 1962, Dewey stated, "Through their games they learn about the work and play of the grown-up world" (Musthafa, 2001, p.3). With strong support from these early childhood theorists and other scholars, play has been a major component of early childhood curriculums (Musthafa, 2001).

Dewey believed that the role of the early childhood teacher was to not only provide an appropriate physical 
environment including interest areas, but to ask questions during children's play and provide extensions that would integrate the child's understanding of experiences across several curriculum areas. This emphasis on questioning strategies remains a principle of appropriate early childhood education today (Wimer, Ridenour, Thomas, \& Place, 2001). Specifically, higher order questions help to develop critical thinking skills. Teachers can stimulate children's thinking skills in the block area for example by asking higher order or open-ended questions such as, "Tell me about your building." and "How can a person get inside your building?" (Gellens, 2000).

\subsection{Research Questions}

The formulations of the following research questions are based on the theoretical perspective that prekindergarten best practices in the area of higher order questioning for a child at this stage of development is crucial for kindergarten school readiness and ultimate school success. The following research questions were addressed in this study:

1) As higher order questioning increases during interest area time, does test performance in the mathematical and language concepts area of the DIAL-3 increase?

2) Does teacher training in verbal interaction (specifically higher order questioning) affect teachers and paraprofessionals' attitudes regarding verbal interaction with students?

\subsection{Hypotheses}

Relating to research question number one:

As higher order questioning increases during interest area time, test performance in the mathematical and language concepts area of the DIAL-3 increases.

Relating to research question number two:

Teacher training in verbal interaction (specifically higher order questioning) affects teachers and paraprofessionals' attitudes regarding verbal interaction with students.

\section{Review of the Literature}

A major factor in the increase of public school awareness concerning the importance of preschool services is the large number of children who are failing to meet educational standards in the early grades (Bryant, 2005). "Thirty percent of all American children begin school unable to maximally profit from the educational experience they will encounter" (Ferrandino, 2005, p.3). This percentage is much higher for impoverished children. School readiness is extremely important and thereby nearly every educational benchmark is related to school readiness (Ferrandino, 2005). In addition, research indicates that prekindergarten students have a greater capacity to learn than was previously known. However, statewide universal prekindergarten is still not fully developed throughout the United States, thus not providing all children equal opportunity to enter school ready to learn (Research and Policy Committee of the Committee for Economic Development, 2002, p.viii).

Along with concerns about school readiness, educators have recently grown interested in brain development research (Marshall et al., 2002). Both of these issues have heightened the interest in early education and the ways in which it can support young children's cognitive and language development. The research indicates that the children who attend high quality prekindergarten programs, particularly those who offer greater language stimulation, display more advanced cognitive and language development skills (Marshall et al., 2002).

According to the 2003-2004 Louisiana State Education Progress Report (2005), student achievement scores on national assessments have consistently been lower than most of the other states in the American educational system. Louisiana ranked $48^{\text {th }}$ of 50 states in fourth grade reading performance and $47^{\text {th }}$ of 50 states in fourth grade mathematics performance on the National Assessment of Educational Progress (NAEP) in 2003 (p.11). The lack of school readiness in this southern state may contribute to poor student achievement statewide. The sample population being studied is within the statewide school system, and more specifically, within the local school district. Ultimately, it is anticipated that the results of this study will positively affect the local school system and may extend statewide.

The No Child Left Behind federal education bill which passed in 2001 addresses increased accountability for schools throughout the nation to seek higher student achievement. States must ensure that all students, including the high-risk population, achieve academic proficiency. They must document school progress through annual reports. Schools that do not make progress must provide supplemental services to ensure that all students achieve academic success. According to the State Legislative Report (2004), Wisconsin Governor Jim Doyle explained that as K-12 education becomes more rigorous with mandated standards and guidelines, all children will need high quality prekindergarten services to be afforded an equal chance to succeed by reducing gaps in school performance (p.2). 
In addition to the cognitive benefits associated with preschool, longitudinal studies have identified many positive and significant relationships between preschool participation and task-related, social, and attitudinal outcomes. In particular, preschool attendees were found to have fewer referrals for remedial classes; preschool graduates were less likely to repeat grades; preschool graduates had fewer failing grades throughout their school; preschool graduates completed high school in greater numbers. Preschool attendees were also rated higher than non-preschool attendees on measures of academic motivation, on-task behavior, capacity for independent work, and time spent on homework. These studies also revealed that those who attended preschool had higher scores on measures of self-esteem, attitudes toward school and aspirations for their futures. Additionally, preschool graduates were more likely to enroll in post-secondary programs in adulthood (Cotton \& Conklin, 2001).

Student achievement in most states is a significant issue and one that is taken seriously by educational and governmental leaders. In order to create an educational system in which students leave school armed with the skills they need to compete in a global society, educators must take the responsibility for educational reform and provide students with an educational foundation for learning starting with best practices at the prekindergarten grade level. Best practices require early childhood teachers to continuously think about what they are doing and how it will foster children's development and produce real and lasting learning (Epstein, 2007).

School readiness as defined by the NAEYC "involves more than just children. School readiness is about children, families, early environments, schools, and community" (National Association for the Education of Young Children, 2004, p.1). In 2004, the National Association for the Education of Young Children (NAEYC) issued a joint position statement regarding early learning standards. The organization states that "the first years of life are critical for later outcomes" (p.2). Young children are born with the desire to learn and that desire can be supported or undermined depending on the child's early experiences. High quality early childhood education can provide exposure to skills needed to promote intellectual, language, physical, social and emotional development, creating school readiness and ultimately promoting later academic and life success (National Association for the Education of Young Children, 2004). According to the NAEYC, high quality prekindergarten involves best practices and best practices include educators providing opportunities for children to speak, carefully listening to children as they speak, and offering expansions of their sentences to enhance meaning of their communication (Bredekamp \& Copple, 1997). "The ability to represent thoughts and feelings verbally allows children to develop new social strategies and to participate with others in many ways" (Bredekamp \& Copple, 1997, p.109).

Research on early care and education and children's development reveals that high quality care is associated with outcomes that all parents desire in their children, ranging from cooperation with adults to the ability to initiate and sustain positive exchanges with peers, to early competence in math and reading (Marshall et al., 2002). During the preschool years, language development, especially vocabulary growth and conversational skills, continues. It is generally agreed that vocabulary learning is not accomplished through formal instruction. Instead, the meaning of new words is usually acquired when children interact with other more skilled language users within their natural environment. The development of conversational skills requires children's active interaction with other people. In order to communicate with others effectively, children need to learn how to negotiate, take turns, and make relevant as well as intelligible contributions. Through interacting with other more experienced language users, children modify and elaborate their sentences in response to requests for more information ( $\mathrm{Lu}, 2000, \mathrm{p} .4)$

With regard to higher-order questioning as an effective strategy in teacher-child verbal interactions, Wimer (2001) stated that "higher order questioning encourages students to think critically, and, therefore, is powerful for learning" (p.84). Perhaps the best known and most widely used paradigm in education is the Bloom, Englehart, Furst, Hill, and Krathwohl (1956) taxonomy. This typology assumes that the cognitive level of the question is determined by the response requested by the teacher. Higher level cognitive functioning has been presumed to be more likely when students are engaged in synthesizing or evaluating information than when they are engaged in the simple recall of information. Educators commonly have assumed that teachers who ask higher order questions foster critical thinking skills (Wimer et al., 2001). Critical thinking skills can be applied to the early childhood classroom experience to enhance learning in the early years and promote kindergarten school readiness. An illustration of higher order questioning that may be utilized during interest area time would be in the manipulative/math area, where the teacher may ask higher order or open-ended questions such as, "What are you making with the linking cubes?" and "How can you make a pattern?" (Gellens, 2000).

For the purposes of this study, higher order questioning was applied to the most important time period of the prekindergarten day: interest area time or center time. Interest areas are the primary setting in which children learn, "where child-initiated learning usually begins and where teachers observe children to consider what kinds of teacher-directed learning is needed and what teacher interactions will best guide learning" (Dodge, Colker, \& Heroman, 2002, p.187). Interest areas offer opportunities for teachers to teach content as children explore materials. For example, when children observe a caterpillar in the Discovery Area, and the teacher talks with them 
about how it moves and eats leaves, the children gain science knowledge (Dodge et al., 2002). Because higher-order questioning encourages students to critically think, applying this strategy during interest area time is a constructive method of having students critically think as they are engaged in hands-on, active learning, thereby creating a higher level of learning. Interest areas vary in each prekindergarten classroom. An example floor plan displaying common interest areas is included in Appendix A. In addition, a list of the interest areas and their content are included in Appendix B.

Teachers are key change agents in the classroom; therefore attention must be provided to adequate teacher training in specific strategies that promote increased learning. Strong prekindergarten programs can guarantee that students are well prepared for kindergarten. While many factors determine whether a child is school ready for kindergarten, one of the most important factors is the quality of teachers (Whitebook, 2003). Studies have shown that prekindergarten teachers who possess a bachelor's degree coupled with specialized training in early childhood development and education provide the best preparation for the advancement of prekindergarten students to the next level (Whitebook, 2003). In one study where researchers implemented teacher training in Washington, DC, the authors explained that when teachers were asked what kinds of learning strategies within professional development in-services were most useful, the teachers responded that the initial workshop including demonstrations was crucial in providing a basic understanding of strategies instruction. One teacher stated, "When you can see how it's done by somebody else, then you can do it or you can have more ideas of how to go about doing it in your own way" (National Capital Language Resource Center: Department of Education, 2000).

\section{Methodology}

Quantitative and qualitative data were collected in this study which included a single group, pretest-posttest design. This design involved the administration of a pretest, the implementation of the experimental treatment for participants, and the administration of a posttest. The effects of the experimental treatment were measured by comparing the pretest and posttest scores (Gall, Gall, \& Borg, 2003). The purpose of using this research design was to determine whether a new teaching strategy (higher order questioning during interest area time) would improve the language and mathematical skills of prekindergarten children - ultimately leading to improved kindergarten readiness.

Kindergarten readiness was measured by comparing the pre-test scores to the post-test scores of the 45 prekindergarten students within three prekindergarten classrooms in a low-socioeconomic area school. Changes in teacher practice were self-evaluated by the teachers and paraprofessionals using recordings which consisted of tallying the quantity of higher-order questions asked to each child per week on a charting form created by the researcher (See Appendix C). These teacher recordings served as a quantitative measure of how many higher order questions the teachers asked students as well as how many of these questions the students were exposed to within one school week. This section is divided into six sections: (1) methodology; (2) participants; (3) instruments; (4) procedures; (5) limitations; and (6) anticipated outcomes.

\subsection{Participants}

The participants in this study were 45 prekindergarten students within three prekindergarten classrooms in a low-economic area school. The population sample was selected by collecting data from the local school district. Through conducting informal interviews with the Region Three Coordinator as well as the Superintendent of schools and the Title One Supervisor, the researcher selected the target school based on the following criteria. The target school was considered a medium performance school within the local school district, according to the Developmental Indicators for the Assessment of Learning/ Third Edition (DIAL-3) scores. The target school contained the largest student population of the 13 elementary schools within the school district with 113 students. In the target school, almost $64 \%$ of the students received free or reduced lunches. Students qualify for the free or reduced lunch program by meeting the district criteria for low family income, thereby granting free or reduced fees for student lunch services. Over $59 \%$ of the students in the target school scored in the $1^{\text {st }}$ or $2^{\text {nd }}$ quartile on the DIAL-3 assessment, thus scoring below the accepted standard. By selecting the most populated elementary school in the district, more prekindergarten services are available for research. Prior to the first phase of the implementation of this study, approval was received by the Institutional Review Board and permission was granted from the local school district. Of the 45 student participants in the study, 18 (40\%) were female and $27(60 \%)$ were male. The students attended prekindergarten in a local low-socioeconomic school and were all within the 3 to 4-year-old range. The sample population included 45 students who were assigned to three classrooms with 15 students each.

\subsection{Instruments}

The assessment instrument that was utilized to answer the first research question is the Developmental Indicators for the Assessment of Learning/ Third Edition (DIAL-3), which has been developed by the American Guidance 
Service (AGS). The first research question asks when higher order questioning increases during interest area time, does test performance in the mathematical and language concepts area of the DIAL-3 increase? The DIAL-3 is a screening test designed to identify young children in need of further diagnostic assessment. DIAL-3 items assess developmental skills that are the foundation for academic learning and successful classroom functioning (Mardell-Czudnowski \& Goldenberg, 1997). This test is an individually administered, 30 minute screening to assess the development of children between the ages of birth to 11 years old. Although individual children are screened, the testing procedures are designed to handle large numbers of children; different examiners (called operators) administer the Motor, Mathematical Concepts, and Language subtests to a child, who moves from one testing area to another. Special qualifications are not required for operators (Salvia \& Ysseldyke, 2004). The Motor subtest includes catching beanbags, jumping, hopping, building with blocks, cutting with scissors, and writing one's own name. The Mathematical Concepts area includes identification of colors, rapid color naming, rote counting, using blocks to demonstrate positions, and sorting by shapes. The Language Concepts area includes providing personal data (name, age), articulation (repeating the names of objects), letters and sounds, rhyming, and oral problem solving about social situations. Each area includes a social behavior section that is rated by the operator during the developmental testing. The self-help section and the social development section are in the form of questionnaires rated by parents (Salvia \& Ysseldyke, 2004). Information received from parents, who see the child in his or her natural environment, adds to the social and ecological validity of the test in ways that standardized assessments cannot duplicate (Mardell-Czudnowski \& Goldernberg, 1998). Although the social behavior, self-help, and social development area scores are not included in the sum of each area, this additional information can provide the basis for further assessment in these areas. The DIAL-3 has been designed to meet all standards of technical adequacy (norms, validity, and reliability). The researcher utilized both the Language Concepts area and the Mathematical Concepts area of the DIAL-3 instrument to assess language and mathematical developmental skills of prekindergarten students participating in this study. DIAL-3 scores that were acquired at the beginning of the prekindergarten school year were gathered from the school district upon IRB approval. To minimize confidentiality factors, the researcher used the utmost care in keeping the research information private. The students were given an assumed name and number that was used on all data gathered in this study. This research information and the assumed names and numbers are presently kept in two different drawers in a locked cabinet in the researcher's office and will remain there for 36 months.

To answer the second research question which asks if teacher training in verbal interaction (specifically higher order questioning) affects teachers and paraprofessionals' attitudes regarding verbal interaction with students, before and subsequent to the implementation of this study, the teachers and paraprofessionals completed a questionnaire (See Appendix D). Both the pre and post questionnaires utilized a Likert Scale (1-5) with a score of 1 meaning strongly disagree and a score of 5 meaning strongly agree. These questionnaires enabled the teachers and paraprofessionals to provide insight as well as qualitative ideas concerning the implementation.

\subsection{Procedures}

Three prekindergarten classrooms in a low-economic area school made up the study site. During the implementation of this study, the 45 students in the sample actively participated in appropriate teacher-child verbal interactions within the interest area time period of the prekindergarten day. The researcher spent two hours (interest area time) in each classroom one day per week during the first three months of the prekindergarten school year. When the researcher was not present, the teachers and paraprofessionals within the three classrooms continued the implementation throughout the school week. The students also participated in a pre-test (DIAL-3) and a post-test (DIAL-3) in order for the researcher to determine the impact of the intervention.

During the period of the study, prekindergarten teachers and paraprofessionals within the selected classrooms received in-service training. This training consisted of the researcher modeling higher-order questioning during interest area time in each classroom one day per week. The teachers and paraprofessionals observed the process presented by the researcher and continued the process throughout the school week. To allow for questions and to provide feedback regarding the implementation of this process, the researcher met with the teachers and paraprofessionals at additional times dependent on their school schedules. The teacher recordings consisted of tallying the number of higher-order questions asked to each child per week on a charting form created by the researcher. These tally marks were recorded by the teacher and paraprofessional (using the honor system) and this information was collected on a weekly basis by the researcher. Utilizing the honor system by trusting certified teachers to tally their own implementation of higher order questions was both ethical and practical with regard to this study. Furthermore, self-evaluation fosters personal growth and a heightened sense of self-awareness. One of the newest trends in teacher education is improving reflective skills and if administrative educators provide opportunities for teachers to practice thoughtful reflection and self-monitoring, the students may model equally appropriate, higher caliber standards of their own (Beck, Livne \& Bear, 2005). Providing teachers opportunities to monitor their own actions is a professional skill and professional knowledge is reshaped through the process of 
self-reflection and self-evaluation (Attard \& Armour, 2005). In addition to teacher recordings, before and subsequent to the implementation of this study, the teachers and paraprofessionals completed a questionnaire. These questionnaires allowed the teachers and paraprofessionals to provide insight as well as qualitative ideas concerning the implementation.

\subsection{Data Analysis Procedures}

At the end of the intervention, data were collected, recorded, organized, and analyzed. Data included DIAL-3 scores of the 45 prekindergarten students, the completed charting records, and both pre and post questionnaires from the teachers and paraprofessionals within the three classrooms in the target school. The DIAL-3 scores were analyzed, and the results were organized in table formats utilizing the Statistical Package for the Social Sciences (SPSS) software. Specifically, the data were analyzed by chi-square tests that determine whether an observed measure of pretest and posttest gains differ significantly from a chance distribution of gain. The Analysis of Variance (ANOVA) statistical method was utilized to determine whether the pretest and the posttest mean was statistically significant (Gall, Gall, \& Borg, 2003). These procedures were used to answer the first research question.

The questionnaires that were administered to the teachers and paraprofessionals both before and following the intervention were developed by the researcher based on the content of the study. The responses were measured using a Likert Scale representing the degree to which the participants rate their attitudes and feelings regarding the specific questions. This numerical system allowed data to be quantified, analyzed and discussed utilizing percentages of teachers and paraprofessionals that agreed, disagreed or remained neutral with regard to the specified questions. This procedure answered the second research question.

\section{Results}

The purpose of this section is to present results for the research questions formulated to respond to the purpose of this study. The purpose of this study was to identify whether the strategy of higher order questioning during interest area time had a positive effect on kindergarten school readiness (specifically focusing on mathematical and language concepts) for students in a low-economic area school. Evidence from the Developmental Indicators for the Assessment of Learning/ Third Edition (DIAL-3) scores (completed upon entering kindergarten) established that the students in the target school were not kindergarten ready. The following are the research questions addressed in this study: (1) As higher order questioning increases during interest area time, does test performance in the mathematical and language concepts area of the DIAL-3 increase? (2) Does teacher training in verbal interaction (specifically higher order questioning) affect teachers and paraprofessionals' attitudes regarding verbal interaction with students?

Statistical analysis of the data obtained from the DIAL-3 was used to answer both research questions and provide a positive response to both hypotheses. Additionally, unexpected findings are included in this section as well as the following tables: (1) a Descriptive Statistics table (Table 1), (2) an Analysis of Variance (ANOVA) table (Table 2), (3) a Questionnaire Results table, (4) a Correlations (Percent) table (Table 4), (5) an Analysis of Variance (ANOVA - Gender) table (Table 5), (6) an Analysis of Variance (ANOVA - Raw and Converted Score), and lastly (7) an Analysis of Variance (ANOVA - Behavior by Gender). Frequencies, percentages, means, standard deviations, correlations and significance levels are utilized to present the data.

\subsection{Findings}

The findings include responses to both research questions as well as additional unexpected findings that provide notable information regarding the demographic nature of the student participants. The research questions are based on the theoretical perspective that prekindergarten best practices in the area of higher order questioning for a child at this stage of development is crucial for kindergarten school readiness.

\subsubsection{Research Question One}

Research question one asks as higher order questioning increases during interest area time, does test performance in the mathematical and language concepts area of the DIAL-3 increase? The following tables (Tables 1 and 2) demonstrate considerable developmental growth during the implementation period of the study. Statistical evidence indicates that test performance in the mathematical and language concept area of the DIAL-3 increases as higher order questioning increases.

The significance was determined by utilizing the Analysis of Variance (ANOVA) statistical method. Throughout the implementation of this study, higher order questioning was purposely provided to the students by the researcher as well as the participating teachers during interest area time each day per week during a 3 month period (12 weeks). During implementation of the study, test performance scores for all students improved by $50 \%$. According to Table 1, the mean of the Mathematical Concepts pretest total is 10.84 and the Language Concepts Pretest total is 
10.58 with the posttest totals of the Mathematical Concepts (16.42) and the Language Concepts (16.69) being much higher indicating developmental growth.

According to Table 2, ANOVA was conducted for the mathematical concepts and the language concepts total scores between groups. The point .000 level indicates significant differences in student performance between pre and posttests. Displayed within Table 2 are percentage calculations of the mathematical concept total test and the language concept total test.

Table 1. Group Statistics for Pre and Post Test Scores

\begin{tabular}{llllll}
\hline & PRE OR POST & N & Mean & Std. Deviation & Std. Error Mean \\
\hline Mathematical Concept Total Test & PRETEST & 45 & 10.84 & 5.927 & .884 \\
& POSTTEST & 45 & 16.42 & 4.998 & .745 \\
\hline Language Concept Total Test & PRETEST & 45 & 10.58 & 5.020 & .748 \\
& POSTTEST & 45 & 16.69 & 4.358 & .650 \\
\hline Percent of Mathematical Concept Total Test & PRETEST & 45 & 40.1646 & 21.95342 & 3.27262 \\
& POSTTEST & 45 & 59.8354 & 20.48416 & 3.05360 \\
\hline Percent of Language Concept Total Test & PRETEST & 45 & 39.1770 & 18.59394 & 2.77182 \\
& POSTTEST & 45 & 61.8107 & 16.14064 & 2.40610 \\
\hline
\end{tabular}

Table 2. Anova (Analysis of Variance between Pre and Posttests)

\begin{tabular}{lllllll}
\hline & Pre and Post & Sum of Squares & df & Mean Square & F & Significance \\
\hline \multirow{3}{*}{ Mathematical Concept Total Test } & Between Groups & 700.011 & 1 & 700.011 & 23.291 & .000 \\
& Within Groups & 2644.889 & 88 & 30.056 & & \\
& Total & 3344.900 & 89 & & & \\
\hline \multirow{2}{*}{ Language Concept Total Test } & Between Groups & 840.278 & 1 & 840.278 & 38.025 & .000 \\
& Within Groups & 1944.622 & 88 & 22.098 & & \\
\hline \multirow{3}{*}{$\begin{array}{l}\text { Percent of Mathematical Concept Test } \\
\text { Total }\end{array}$} & Between Groups & 8706.142 & 1 & 8706.142 & 19.314 & .000 \\
& Within Groups & 39668.343 & 88 & 450.777 & & \\
\hline \multirow{2}{*}{$\begin{array}{l}\text { Percent of Language Concept Total } \\
\text { Tes }\end{array}$} & Total & 48374.486 & 89 & & & \\
& Wetween Groups & 11526.444 & 1 & 11526.444 & 38.025 & .000 \\
& Total Groups & 26675.202 & 88 & 303.127 & & \\
\hline
\end{tabular}

\subsubsection{Research Question Two}

Research question two asks does teacher training in verbal interaction (specifically higher order questioning) affect teachers and paraprofessionals' attitudes regarding verbal interaction with students? Statistical evidence indicates that teacher training in higher order questioning affects teachers and paraprofessionals' attitudes regarding verbal interaction with students. To this end, questionnaires were provided to 3 teachers and 3 paraprofessional participants (six educators) and were completed prior to and following the implementation of this study (See Table 3 and Appendix E). The questionnaires were created by the researcher to align with the intervention and the teachers and paraprofessionals' attitudes toward the intervention. These questionnaires were completed, collected and analyzed for the purpose of providing insight as well as qualitative ideas concerning the implementation. Both the pre and post questionnaires were measured utilizing the Likert Scale (1-5) with a score of 1 meaning strongly disagree and a score of 5 meaning strongly agree. In the pre-questionnaire, when the teachers/paraprofessionals were asked if they felt the study would be worthwhile because the students need to learn to think critically, all 6 $(100 \%)$ of the participants responded with a score of 5 (Strongly Agree). The teachers and paraprofessionals were also asked in the pre-questionnaire if they felt that the students were not cognitively challenged enough by teachers at Interest Area Time for which four out of six (67\%) of the teachers strongly agreed, one teacher (17\%) slightly 
agreed, and one teacher (17\%) felt neutral regarding this question. Teachers/paraprofessionals were asked if they felt higher order questioning in Interest Areas would improve students' cognitive ability and ultimately make them more kindergarten ready. Five out of six teachers and paraprofessionals (83\%) strongly agreed and only one teacher $(17 \%)$ slightly agreed. One of the teachers added the comment that she felt that students were not cognitively challenged enough at interest area time because of the shortage of staff and the increased number of students to serve in a single classroom setting (See Table 3 and Appendix E).

In the post-questionnaire, when the teachers/paraprofessionals were asked if they felt that the study was worthwhile because students need to learn to think critically, they all (100\%) responded that they strongly agreed. They also agreed that purposely asking higher order questions during interest area time has improved students' cognitive ability and ultimately made them more kindergarten ready. Five out of the 6 teachers and paraprofessionals $(83 \%)$ strongly agreed that they felt as though through the implementation of this study they became more aware of higher order questioning and therefore more verbally interactive with students during interest area time. One teacher (17\%) slightly agreed that she became more verbally interactive. She added the comment that in her classroom, they already practiced higher order questioning, but keeping track of the number of questions has made her more aware of the importance of such questions on test and school performance (See Table 3 and Appendix E). The following table (Table 3) reveals pre intervention and post intervention results for the questions posed in the questionnaires.

Table 3. Questionnaire Results

\begin{tabular}{|c|c|c|c|c|c|}
\hline Pre and Post Question (shorter version) & $\begin{array}{l}1=\text { Strongly } \\
\text { Disagree }\end{array}$ & $\begin{array}{l}2=\text { Slightly } \\
\text { Disagree }\end{array}$ & $\begin{array}{l}3= \\
\text { Neutral }\end{array}$ & $\begin{array}{l}4=\text { Slightly } \\
\text { Agree }\end{array}$ & $\begin{array}{l}5=\text { Strongly } \\
\text { Agree }\end{array}$ \\
\hline 1. Study will be worthwhile & & & & & $100 \%$ \\
\hline 1. Study was worthwhile - post intervention & & & & & $100 \%$ \\
\hline $\begin{array}{l}\text { 2. Students not challenged enough } \\
\text { 2. Students not challenged enough - post } \\
\text { intervention }\end{array}$ & & & $\begin{array}{l}17 \% \\
17 \%\end{array}$ & $17 \%$ & $\begin{array}{l}67 \% \\
83 \%\end{array}$ \\
\hline $\begin{array}{l}\text { 3. Teachers need to be more verbally } \\
\text { interactive } \\
\text { 3. Teachers are more verbally interactive - post } \\
\text { intervention }\end{array}$ & & & & $17 \%$ & $\begin{array}{l}100 \% \\
83 \%\end{array}$ \\
\hline $\begin{array}{l}\text { 4. Higher order questioning will improve } \\
\text { students' cognitive ability. } \\
\text { 4. Higher order questioning has improved } \\
\text { students' cognitive ability - post intervention }\end{array}$ & & & & $17 \%$ & $\begin{array}{l}83 \% \\
100 \%\end{array}$ \\
\hline $\begin{array}{l}\text { 5. Intervention will be simple to carry out. } \\
\text { 5. Intervention was simple to carry out - post } \\
\text { intervention }\end{array}$ & & & & $33 \%$ & $\begin{array}{l}67 \% \\
100 \%\end{array}$ \\
\hline
\end{tabular}

Additional findings are expected when new information presents itself. Demographic data were collected along with the DIAL-3 scores, thereby presenting additional information worth mentioning. Additional analyses were conducted on the data to formulate the following conclusions.

First, there was a correlation in the findings that those who did well in Mathematics also did well in Language skills (See Table 4). Second, behavior was a mentionable factor in that there was a statistically significant correlation between positive behavior and better scores (See Table 4 and Table 7). Third, gender was significant in test performance, indicating that the female students outperformed the male students on the DIAL-3 test (See Table 5). Table 6 displays the behavior total raw and converted scores and Table 7 demonstrates the behavior observation score by gender.

The first two additional findings are displayed in Table 4. The students who did well in Mathematics also did well in Language ( $r .808)$. Additionally, a statistically significant correlation between positive behavior and better scores is evidenced in the results among the Mathematical pretest total (r.634) and the Language pretest total $(r .633)$ as well as the Mathematical posttest total (r.595) and the Language posttest total (r.565). 
Table 4. Correlations (Percent)

\begin{tabular}{|c|c|c|c|c|c|c|}
\hline Description & $\begin{array}{l}\text { Statistical } \\
\text { Test }\end{array}$ & $\begin{array}{l}\text { Percent of } \\
\text { Mathematical } \\
\text { Concepts } \\
\text { Pretest Total }\end{array}$ & $\begin{array}{l}\text { Percent of } \\
\text { Language } \\
\text { Concepts } \\
\text { Pretest Total }\end{array}$ & $\begin{array}{l}\text { Percent of } \\
\text { Mathematical } \\
\text { Concepts } \\
\text { Posttest Total }\end{array}$ & $\begin{array}{l}\text { Percent of } \\
\text { Language } \\
\text { Concepts } \\
\text { Posttest Total }\end{array}$ & $\begin{array}{l}\text { Behavior } \\
\text { Score } \\
\text { (Percent) }\end{array}$ \\
\hline \multirow{3}{*}{$\begin{array}{l}\text { Percent of } \\
\text { Mathematical } \\
\text { Concepts } \\
\text { Pretest Total }\end{array}$} & Pearson & 1 & $.808(* *)$ & $.783(* *)$ & $.629(* *)$ & $.634(* *)$ \\
\hline & Sig. (2-tailed) & & .000 & .000 & .000 & .000 \\
\hline & $\mathrm{N}$ & 45 & 45 & 45 & 45 & 45 \\
\hline \multirow{3}{*}{$\begin{array}{l}\text { Percent of } \\
\text { Language } \\
\text { Concepts } \\
\text { Pretest Total }\end{array}$} & $\begin{array}{l}\text { Pearson } \\
\text { Correlation }\end{array}$ & $.808(* *)$ & 1 & $.792(* *)$ & $.787(* *)$ & .633 \\
\hline & Sig. (2-tailed) & .000 & & .000 & .000 & .000 \\
\hline & $\mathrm{N}$ & 45 & 45 & 45 & 45 & 45 \\
\hline \multirow{3}{*}{$\begin{array}{l}\text { Percent of } \\
\text { Mathematical } \\
\text { Concepts } \\
\text { Posttest Total }\end{array}$} & $\begin{array}{l}\text { Pearson } \\
\text { Correlation }\end{array}$ & $.783(* *)$ & $.792(* *)$ & 1 & $.725(* *)$ & $.595(* *)$ \\
\hline & Sig. (2-tailed) & .000 & .000 & & .000 & .000 \\
\hline & $\mathrm{N}$ & 45 & 45 & 45 & 45 & 45 \\
\hline \multirow{3}{*}{$\begin{array}{l}\text { Percent of } \\
\text { Language } \\
\text { Concepts } \\
\text { Posttest Total }\end{array}$} & Pearson & $.629(* *)$ & $.787(* *)$ & $.725(* *)$ & \multirow{3}{*}{$\begin{array}{l}1 \\
45\end{array}$} & $.565(* *)$ \\
\hline & ention & .000 & .000 & .000 & & .000 \\
\hline & $\mathrm{N}$ & 45 & 45 & 45 & & 45 \\
\hline \multirow{3}{*}{$\begin{array}{l}\text { Behavior Score } \\
\text { (Percent) }\end{array}$} & $\begin{array}{l}\text { Pearson } \\
\text { Correlation }\end{array}$ & $.634(* *)$ & $.633(* *)$ & $.595(* *)$ & $.565(* *)$ & 1 \\
\hline & Sig. (2-tailed) & .000 & .000 & .000 & .000 & \\
\hline & $\mathrm{N}$ & 45 & 45 & 45 & 45 & 45 \\
\hline
\end{tabular}

**Correlation is significant at the 0.01 level (2-tailed).

The third additional finding addresses gender in that the gender gap improved in math and language over the implementation period because the variance of the distribution of the scores was reduced. Table 5 presents these additional findings utilizing the analysis of variance (ANOVA) technique which is a powerful and versatile statistical method that allows the researcher to compare differences among more than one sample group (Sprinthall, 2003). The concern of the researcher is the statistical significance of the findings. The two groups represented in the following tables are 18 female students and 27 male students. Within Table 5, the first row indicates that the Mathematical Concepts section total from the pretest is not significant (.074) because it is more than the typical alpha level (.05). The second row indicates that the Language Concepts section total from the pretest is also not significant (.063) because it is more than the typical alpha level. The third row indicates that the Mathematical Concepts section posttest is statistically significant (.21) because it is less than the typical alpha level (.05). The Language Concepts section posttest is not significant (.197) because it is more than the typical alpha level. The fifth row and additional finding indicates that gender was not a factor in behavior results, but was significant (.047) in test performance. Overall, the table indicates growth in both Mathematical and Language skills. 
Table 5. ANOVA (Analysis of Variance by Gender on Pre and Posttests)

\begin{tabular}{|c|c|c|c|c|c|c|}
\hline $\begin{array}{l}\text { Source of } \\
\text { Variation }\end{array}$ & $\begin{array}{l}\text { Treatments \& } \\
\text { Errors }\end{array}$ & $\begin{array}{l}\text { Sum of } \\
\text { Squares }\end{array}$ & $\begin{array}{l}\text { Df - Degrees } \\
\text { of Freedom }\end{array}$ & Mean Square & F Ratio & Significance \\
\hline \multirow{3}{*}{$\begin{array}{l}\text { Mathematical } \\
\text { Concepts } \\
\text { Pretest Total }\end{array}$} & Between Groups & 112.133 & 1 & 112.133 & 3.363 & .074 \\
\hline & Within Groups & 1433.778 & 43 & 33.344 & & \\
\hline & Total & 1545.911 & 44 & & & \\
\hline \multirow{3}{*}{$\begin{array}{l}\text { Language } \\
\text { Concepts } \\
\text { Pretest Total }\end{array}$} & Between Groups & 86.700 & 1 & 86.700 & 3.647 & .063 \\
\hline & Within Groups & 1022.278 & 43 & 23.774 & & \\
\hline & Total & 1108.978 & 44 & & & \\
\hline \multirow{3}{*}{$\begin{array}{l}\text { Mathematical } \\
\text { Concepts } \\
\text { Posttest Total }\end{array}$} & Between Groups & 129.515 & 1 & 129.515 & 5.745 & .021 \\
\hline & Within Groups & 969.463 & 43 & 22.546 & & \\
\hline & Total & 1098.978 & 44 & & & \\
\hline \multirow{3}{*}{$\begin{array}{l}\text { Language } \\
\text { Concepts } \\
\text { Posttest Total }\end{array}$} & Between Groups & 32.033 & 1 & 32.033 & 1.714 & .197 \\
\hline & Within Groups & 803.611 & 43 & 18.689 & & \\
\hline & Total & 835.644 & 44 & & & \\
\hline \multirow[t]{3}{*}{ Behavior Score } & Between Groups & 75.737 & 1 & 75.737 & 4.201 & .047 \\
\hline & Within Groups & 775.241 & 43 & 18.029 & & \\
\hline & Total & 850.978 & 44 & & & \\
\hline
\end{tabular}

The behavioral observations conducted by the researcher were obtained during the posttest. The nine questions included in each observation were contained within

a subsection of the DIAL-3 assessment. Although the social behavior area scores are not included in the sum of each area, this additional information can provide the basis for further assessment in this area. An example of the nine behavioral observation questions and their response options can be viewed in Appendix E. The creation of this appendix was obtained from the DIAL-3 behavioral observation section.

Table 6. ANOVA (Post Behavior Total Raw and Converted Score)

\begin{tabular}{llllll}
\hline & $\mathrm{N}$ & Minimum & Maximum & Mean & Std. Deviation \\
\hline *Behavior Raw Score & 45 & 0 & 18 & 3.42 & 4.398 \\
**Behavior Score (Percent) & 45 & 33.33 & 100.00 & 87.3251 & 16.28805 \\
Valid N (listwise) & 45 & & & &
\end{tabular}

*Behavior Raw Score is based on a range of 0 - 18. A "0" implies highest observed on-task behavior and a "18" implies lowest observed on-task behavior.

Table 7. ANOVA (Post Behavior Observation Score by Gender)

\begin{tabular}{llllll}
\hline Description & Sum of Squares & df & Mean Square & F & Significance \\
\hline Behavior Score Between Groups (raw score) & 75.737 & 1 & 75.737 & 4.201 & .047 \\
Within Groups & 775.241 & 43 & 18.029 & & \\
Total & 850.978 & 44 & & & \\
\hline Behavior Score Between Groups (percent) & 1038.917 & 1 & 1038.917 & 4.201 & .047 \\
Within Groups & 10634.304 & 43 & 247.309 & & \\
Total & 11673.221 & 44 & & & \\
\hline
\end{tabular}




\section{Discussion}

The current study focused on prekindergarten higher order questioning within interest area time and its effect on kindergarten school readiness. Results from the data analyses were presented in the previous section. The focus of this study is expected to increase interest in the benefits of prekindergarten education and promote further studies in the area of teacher-child verbal interactions during interest area time. In this section, the researcher will provide an overview of the dissertation, elaboration and interpretation of results, a discussion of conclusions, relationship of findings to literature review and the implications of the findings. Additionally, limitations of the study will be revealed in order to provide the appropriate context for the interpretation of results. In conclusion, recommendations for further research and a summary of the dissertation will be included. Validated recommendations will be submitted to the state department of education in order to provide data for further studies in this area.

\subsection{Overview}

The purpose of this study was to identify whether the strategy of higher order questioning during interest area time would have a positive effect on kindergarten school readiness (specifically focusing on mathematical and language concepts) for students in a low-socioeconomic area school. Evidence from the Developmental Indicators for the Assessment of Learning/ Third Edition (DIAL-3) scores (completed upon entering kindergarten) establishes that the students in this low-socioeconomic area school were not kindergarten ready. Specifically, prekindergarten students in the target school did not exhibit the skills necessary in mathematical concepts and language concepts for kindergarten school readiness.

To assist in solving the problem, the researcher implemented the strategy of higher order questioning during interest area time in 3 prekindergarten classrooms within the target school. Particularly, the researcher worked with the students in each classroom one day per week for two hours (interest area time). Working with the prekindergarten students involved the researcher entering each interest area within each classroom and addressing each student individually with higher order questions relating to the materials within the specified area. When the researcher addressed the students within the block area, examples of the questions asked were "What are you making with the blocks?" and "How could you make a house with these blocks?" The researcher expanded on the students' answers to these questions by asking additional questions that encouraged the students to critically think and apply skills such as evaluation and analysis to their knowledge base. Additionally, the researcher provided training by modeling this type of questioning for teachers and paraprofessionals in order to assure that this was implemented continuously at interest area time each day during a three-month period.

Early Childhood educators and advocates strive for best practices when teaching young children. One strategy within best practices includes educators taking conversational turns with students, which allows the students to formulate and express their thoughts. Educators asking higher-order and open-ended questions within these deliberate conversations, challenges their cognitive abilities (Epstein, 2007). According to Epstein, "Young children need to be exposed to a rich and varied vocabulary" and this can be accomplished by deliberately creating conversations involving questioning which encourages critical thinking (Epstein, 2007).

The student achievement results of providing teacher training in higher-order questioning techniques during interest area time (the most vital learning time of the prekindergarten day) has provided evidence of increased cognitive development, ultimately increasing student achievement in mathematical and language skills. High-quality prekindergarten services involving best practices are the precursors for kindergarten; therefore, improving teacher-child verbal interactions in prekindergarten ultimately addresses the issue of kindergarten school readiness.

Additionally, teacher perceptions of the importance of higher order questioning in prekindergarten remains constant in that it is a vital part of the preschool curriculum and that in increasing the number of higher order questions asked, student outcomes will improve and ultimately make them more kindergarten ready.

\subsection{Discussion of Findings}

Research question one asks as higher order questioning increases during interest area time, does test performance in mathematical and language concepts area of the DIAL-3 increase? Based upon historical observation and research, it is known that children from low-socioeconomic areas enter the formal school system with limited exposure to higher order questioning and an increase in higher order questioning would be experienced upon entering prekindergarten. Specifically, according to Chin and Phillips (2004), families from different social backgrounds raise their children differently. In comparison to low-socioeconomic area families, middle to upper class parents tend to enroll their children in various age-appropriate organized activities and these activities teach important life skills to children and help develop critical higher order thinking skills. These parents generally nurture their children's skills and talents actively (Chin \& Phillips, 2004). Middle to upper class children are more 
exposed to life skills and critical thinking processes because they are more likely to attend summer-camps, go on vacations, visit libraries and museums, and participate in social events (Chin \& Phillips, 2004). In general, low-socioeconomic background families have limited funds and access to resources, therefore, they believe that as long as they provide food and safety, their children will thrive (Chin \& Phillips, 2004).

Throughout the 3 month implementation of this study, higher order questioning was purposely provided to the students during interest area time each day by both the researcher and the participating teachers. According to the results, increasing the frequency of higher order questioning during interest area time significantly improves the test performance of students with the mathematical and language concepts area of the DIAL-3 assessment. The Analysis of Variance (ANOVA) was used to determine the significance. As evidenced in Table 1, the mean of the Mathematical Concepts pretest total is 10.84 and the Language Concepts Pretest total is 10.58, with the posttest totals of the Mathematical Concepts (16.42) and the Language Concepts (16.69) being much higher. This reflects considerable developmental growth during the implementation portion of the study. Statistical evidence reveals the validity of hypothesis one in that as higher order questioning increases during interest area time, test performance in the Mathematical Concepts and Language areas of the DIAL-3 increases. The strategy of higher order questioning during the prekindergarten grade level is a simple, cost-effective method of improving kindergarten readiness and ultimate student success.

Research question two asks if teacher training in verbal interaction (specifically higher order questioning) affects the attitudes of both teachers and paraprofessionals regarding verbal interaction with students. In an effort to answer this, questionnaires were completed prior to and following the implementation of this study by teachers as well as paraprofessional participants (See Table 3 and Appendix D). These questionnaires were completed, collected and analyzed in an effort to provide both insight and qualitative ideas concerning the implementation. Hypothesis two is true in that training teachers in higher order questioning affects the attitudes of teachers regarding verbal interaction with students. Most of the teachers and paraprofessionals questioned believed that prekindergarten students were not cognitively challenged enough at interest area time. One teacher's comment added insight as to why the participant teachers felt as though students were not cognitively challenged enough at interest area time. She stated that students were not cognitively challenged enough at interest area time because of the large number of students in a single classroom setting as well as staff shortage within the school system. In general, the teachers and paraprofessionals felt that higher order questioning was a crucial part of the preschool curriculum. After the implementation of this study, the teachers and paraprofessionals' beliefs were confirmed in that by increasing the number of higher order questions asked during interest area time, students' cognitive abilities would improve ultimately making them more kindergarten ready.

As demographic data were collected along with the DIAL-3 scores, additional data became notable. The first finding revealed a correlation in that those students who did well in Mathematics also did well in Language skills. This indicates a possible link to development. It can be assumed that those students who are cognitively ready and possess the ability to understand the concepts of analytical thinking about mathematical ideas are also ready and have the ability to understand the concepts of language and communication. The second finding revealed a correlation between positive behavior and better scores. This also indicates a possible link to development in that social development and cognitive development are interrelated. Principle one of Developmentally Appropriate Practices, a position statement of the NAEYC, confirms that the domains of children's development (physical, social, emotional, cognitive) are closely related and that development in one area influences and is influenced by development in other areas (Bredekamp \& Copple, 1997). The third finding indicated that gender was significant in test performance. Female students outperformed the male students on the DIAL-3 test. The developmental level of females to males within the birth-to-five-age group may be a contributing factor in this finding since research demonstrates that females generally achieve developmental milestones at an earlier age than do males (Papalia, Olds, \& Feldman, 2008).

\subsection{Relationship of Findings to Literature Review}

A major factor in the increase of public school awareness concerning the

importance of preschool services is the large number of children who are failing to meet educational standards in the early grades (Bryant, 2005). The research indicates that the children who attend high quality prekindergarten programs, particularly those who offer greater language stimulation, display more advanced cognitive and language development skills (Marshall et al., 2002). The findings from the present study align with the literature because greater language stimulation particularly with regard to higher order questioning within a prekindergarten setting, was shown to advance cognitive skills (See Tables 1 and 2).

The No Child Left Behind federal education bill which passed in 2001 addresses increased accountability for schools throughout the nation to seek higher student achievement. States must ensure that all students, including the high-risk population, achieve academic proficiency. According to the State Legislative Report (2004), 
Wisconsin Governor Jim Doyle explained that as K-12 education becomes more rigorous with mandated standards and guidelines, all children will need high quality prekindergarten services in order to be afforded an equal chance to succeed by reducing gaps in school performance (p.2). The implementation of this study supports the federal education bill by providing a strategy to the prekindergarten setting that proved to have a positive effect on student performance.

According to the NAEYC, high quality prekindergarten involves best practices and best practices includes educators providing opportunities for children to speak, carefully listening to children as they speak, and offering expansions of their sentences to enhance meaning of their communication (Bredekamp \& Copple, 1997). "The ability to represent thoughts and feelings verbally allows children to develop new social strategies and to participate with others in many ways" (Bredekamp \& Copple, 1997, p.109). Higher order questioning allows teachers to expand on statements made by students, thereby enhancing the meaning of their communication. Through the implementation of this study, the students were afforded this opportunity.

Teachers are key change agents in the classroom; therefore attention must be provided to adequate teacher training in specific strategies that bring about increased learning. In one study conducted in Washington, D.C., where researchers implemented teacher training, the authors concurred that when teachers were asked what kinds of learning strategies within professional development in-services were most useful, the teachers responded that the initial workshop including demonstrations was crucial in providing a basic understanding of strategies instruction. One teacher stated, "When you can see how it's done by somebody else, then you can do it or you can have more ideas of how to go about doing it in your own way" (National Capital Language Resource Center: Department of Education, 2000). Through the implementation of this study, teachers were provided training in higher order questioning, and the results confirm that increased learning took place.

\subsection{Implications of Findings}

These findings hold implications for researchers, early childhood educators, and parents and students. The finding that higher order questioning and increased verbal interaction between prekindergarten teachers and students positively impacts student performance implicates that early childhood educators should make this strategy a priority in the prekindergarten classroom. Specifically, increasing the number of higher order questions presented to students during interest area time should have a direct impact on test performance in the Mathematical and Language concept areas. The findings also indicate that teacher training in verbal interaction (specifically higher order questioning) affects teachers and paraprofessionals' attitudes regarding verbal interaction with students. Teachers and paraprofessionals strongly agreed that purposely asking higher order questions during interest area time improves students' cognitive ability and ultimately makes them more kindergarten ready.

\subsection{Limitations of Study}

The findings of this study must be viewed within the context of its limitations. The first limitation was the small sample size. The scope of this study was limited to a sample of 45 prekindergarten students in a low-socioeconomic area school within the local school district. Therefore, the results are limited to the population chosen for this study. Secondly, the study assessed only mathematical and language concepts, excluding other curriculum areas. The third limitation of the study was the limited time of the prekindergarten day in which this study was implemented. It addressed higher order questioning only during interest area time, excluding other times of the prekindergarten day. A fourth limitation of this study was historical comparable data. Comparable data collection was limited because of the sparsity of pertinent data in the area of higher order questioning within the early childhood setting. Finally, due to time restraints, this study was implemented during a three-month period of time, whereas an entire school year implementation may yield higher student outcomes.

\subsection{Recommendations for Research}

The researcher recommends that three developmental skill areas of importance that were exempt from this study be addressed in future studies with regard to kindergarten school readiness. These areas include motor skills, reading skills, and socialization skills, all of which can be tested by utilizing the DIAL-3 assessment. In addition, the present study utilized data obtained within a 3 month period whereas future studies would benefit from a year-long implementation. Additionally, the sample population was limited to 45 students which could be extended to include a larger cross-sectional population to obtain more reliable results. Finally, this study could be replicated utilizing all time periods of the prekindergarten day - not just interest area time.

\section{Conclusion}

This study confirms the importance of purposeful verbal interaction between prekindergarten teachers and students in fostering the development of children for ultimate school success. Math and Language skills at the time of kindergarten entry are strong predictors of academic achievement. Through verbal interaction between the prekindergarten teacher and her students (specifically asking higher order questions) and critical thinking activities 
at interest area time, the future academic success of students will be positively impacted. To expand the literature review, classic works from psychologist Jerome Bruner are mentionable in that he studied perception and thinking. An environment that supports Bruner's theory of learning finds the teacher asking higher order questions (with several possible answers) that require the children to investigate and develop of their own answers (Driscoll \& Nagel, 2005). It is anticipated that the contributions of the present study will encourage future research that will continue to elaborate upon the effects of higher order questioning at the prekindergarten level on kindergarten school readiness.

It was anticipated that this study would provide data regarding the benefits of prekindergarten teacher-child verbal interactions (higher order questioning during interest area time) on kindergarten readiness and student achievement measured by the DIAL-3 scores in a low-socioeconomic area school. Confidently, these results should have a positive impact on prekindergarten education beyond the participating school to both the local and state levels.

Based on the literature review, it is clear that prekindergarten is an invaluable asset to the educational system. Additionally, children's verbal interactions with prekindergarten teachers can determine more than any other program feature, what they learn and how they feel about learning (Epstein, 2007). This study was exploratory in nature and may begin to fill the perceived voids in the literature with regard to the effect of prekindergarten higher-order questioning (within interest areas) on kindergarten school readiness. Advancing the concept of this study will require further research, curriculum development, staff training, child observation, and reflective practice.

\section{References}

Attard, K., \& Armour, K. (2005). Learning to become a learning professional: Reflections on one year of teaching. European Journal of Teacher Education, 28(2), 195-207.

Barnett, S., Hustedt, J., Robin, K., \& Schulman, K. (2004). The state of preschool: 2004 state preschool yearbook. The National Institute For Early Education Research, 1-213.

Beck, R., Livne, N., \& Bear, S. (2005). Teachers' self-assessment of the effects of formative and summative electronic portfolios on professional development. European Journal of Teacher Education, 28(3), 221-244.

Bell, D. \& Thomas, E. (2007). Facilitating respectful diversity professional development. Retrieved June 20, 2007, from http://www.eric.ed.gov/ERICDocs/data/ericdocs2/content_storage_01/0000000b/80/36/20/91.pdf

Bredekamp, S., \& Copple, C. (1997). Developmentally appropriate practice in early childhood programs. Washington, DC: National Association for the Education of Young Children.

Bryant, D., Clifford, D., Early, D., \& Little, L. (2005). Pre-k education in the states. Early Developments, 9(1), $1-29$.

Chin, T., \& Phillips, M. (2004). Social reproduction and child-rearing practices: Social class, children's agency, and the summer activity gap. Sociology of education, 77(3), 185-210.

Conklin, N., \& Cotton, K. (2001). Research on early childhood education. Regional Educational Laboratory, 1-19.

Curry, J. (2003). Prekindergarten expansion grant evaluation (Reports - Evaluative). Austin, Texas: Austin Independent School District: Texas Office of Program Evaluation. (ERIC Document Reproduction Service No. ED481837)

Dodge, D., Colker, L., \& Heroman, C. (2000). The creative curriculum for preschool (4th ed.). Washington, DC: Teaching Strategies, Inc.

Driscoll, A., \& Nagel, N. (2005). Early childhood education, birth-8: The world of children, families, and educators. Boston, MA: Pearson Education, Inc.

Epstein, A. (2007). The intentional teacher: Choosing the best strategies for young children's learning. Washington, DC: National Association for the Education of Young Children.

Example design layout of interest areas. Retrieved June 20, 2007, from http://www.CommunityPlaythings.com

Example floor plan for prekindergarten classroom. Retrieved June 20, 2007, from http://www.CommunityPlaythings.com

Ferrandino, V. (2005). Leading early childhood learning communities: What principals should know and be able to do. National Association of Elementary School Principals, 1-20.

Gall, M., Gall, J., \& Borg, W. (2003). Educational research: An introduction ( $7^{\text {th }}$ ed.). Boston, MA: Pearson Education, Inc. 
Gellens, S. (2000). Activities that build the young child's brain (Guides - Non-Classroom) Sarasota, Florida: Early Childhood Association of Florida, Inc. (ERIC Document Reproduction Service No. ED458941)

Jerald, C. (2007). Believing and achieving issue brief. Center for Comprehensive School Reform and Improvement. $\begin{array}{llll}\text { Retrieved June } & 20, & \text { from }\end{array}$ http://www.eric.ed.gov/ERICDocs/data/ericdocs2/content_storage_01/0000000b/80/37/03/20.pdf

Immersion Teachers' Perceptions of Learning Strategies Instruction. (2000). (Reports - Research). Washington, DC: National Capital Language Resource Center. (ERIC Document Reproduction Service No. ED445520

Lafourche Parish School Board/ Mission Statement and District Goals. (2007). Retrieved June 8, 2007, from http://lafourche.k12.la.us/mission.asp

Leahey, E., \& Guo, G. (2001). Gender differences in mathematical trajectories. Social Forces, 80(2), 713-732. https://doi.org/10.1353/sof.2001.0102

Lu, M. (2000). Language development in the early years. Bloomington, IN: ERIC Clearinghouse on Reading English and Communication. (ERIC Document Reproduction Service No. ED446336)

Mardell-Czudnowski, C., \& Goldenberg, D. (1997). Dial 3: Developmental indicators forthe assessment of learning ( $3^{\text {rd }}$ ed.). United States of America: American Guidance Service, Inc.

Marshall, N., Creps, C., Burstein, N., Glantz, F., Robeson, W., Barnett, S., Schimmenti, J., \& Keefe, N. (2002). Early care and education in Massachusetts public school preschool classrooms. Early Care and Education in Massachusetts Public School Preschool Classrooms: Executive Summary. 1-48.

Morgan, S., Reichert, T., \& Harrison, T. (2002). From numbers to words: Reporting statistical results for the social sciences. Boston, MA: Pearson Education, Inc.

Musthafa, B. (2001). Let children play and develop into readers and writers of their own worlds. (Information Analyses). Bandung, Indonesia. (ERIC Document Reproduction Service No. ED462139)

National Association for the Education of Young Children. (2004). Where we stand on school readiness. Retrieved May 9, 2007, from http://www.tnstarquality.org/refs/ecers_dap.pdf

Papalia, D. E., Olds, S. W., \& Feldman, R. D. (2008). A child's world: Infancy through adolescence (11th ed.) New York, NY: McGraw Hill.

Pinstrup-Anderson, P., \& Cheng, F. (2007). Still hungry. Scientific American, 297(3), 96-103. https://doi.org/10.1038/scientificamerican0907-96

Preschool for all: Investing in a productive and just society. (2002). Research and Policy Committee of the Committee for Economic Development. Retrieved August 3, 2005, from http://www.ced.org/docs/report/report_preschool.pdf

Quality pre-kindergarten for all: State legislative report. (2004). The Trust For Early Education, 1-20.

Rule, A., \& Lord, L. (2003). Activities for differentiated instruction addressing all levels of Bloom's Taxonomy and eight multiple intelligences (Collected Works - General - Guides - Classroom Teacher). Oswego, New York. (ERIC Document Reproduction Service No. ED475517)

Salvia, J., \& Ysseldyke, J. (2004). Assessment: In special and inclusive education. Boston, MA: Houghton Mifflin, Co.

Sprinthall, R. (2003). Basic statistical analysis ( $7^{\text {th }}$ ed.). Boston, MA: Pearson Education Group, Inc.

Tajalli, H., \& Opheim, C. (2005). Strategies for closing the gap: Predicting student performance in economically disadvantaged schools. Educational Research Quarterly, 28(4), 44-54.

Louisiana Department of Education: Division of Early Childhood. (2007). Title 1 Prekindergarten Program Guidelines. Retrieved June 20, 2007, from http://www.doe.state.la.us/lde/uploads/6783.pdf

Louisiana Department of Education: Division of Planning, Analysis and Information Resources. (2005). Louisiana State Education Progress Report. Retrieved August 3, 2005 from http://www.doe.state.la.us/lde/pair/1614.html

Whitebook, M. (2003). Bachelor's degrees are best: Higher qualifications for prekindergarten teachers lead to better learning environments for children. Retrieved August 7, 2007, from http://www.trustforearlyed.org/docs/WhitebookFinal.pdf

Wimer J., Ridenour, C., Thomas, K., \& Place, W. (2001). Higher order teacher questioning of boys and girls in elementary mathematics classrooms. The Journal of Educational Research, 84-91. 
Appendix A. Example Floor Plan of Prekindergarten Interest Areas

\section{Floor Plan for Model Pre K Classroom}

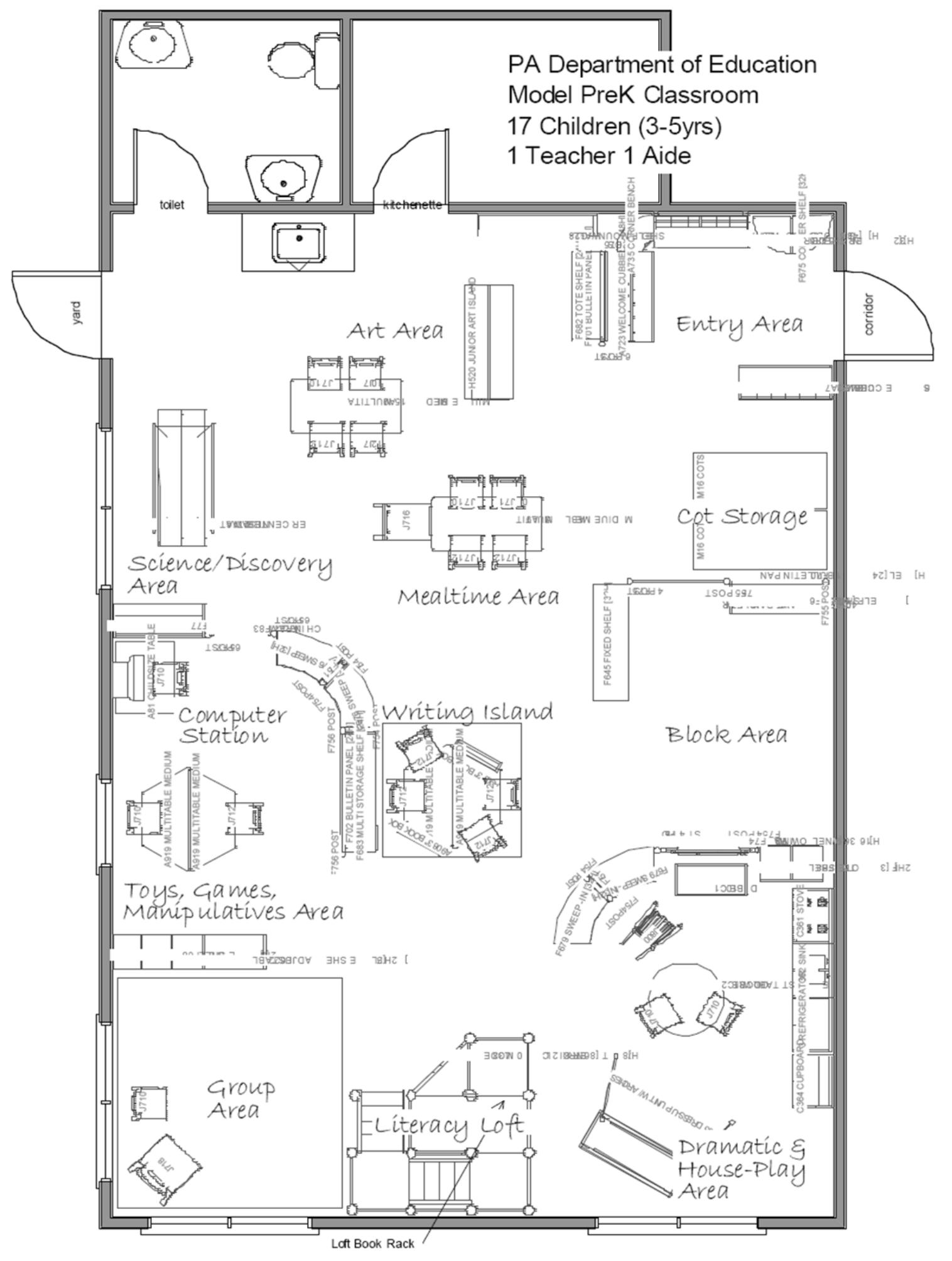

Part A

Example Floor Plan of a Prekindergarten Classroom - (http://www.CommunityPlaythings.com, 2007) 
Appendix B. Interest Areas and Content

\begin{tabular}{|c|c|c|c|c|c|c|c|c|c|c|}
\hline $\begin{array}{l}\text { Curriculum } \\
\text { Area }\end{array}$ & Blocks & $\begin{array}{l}\text { Dramatic } \\
\text { Play }\end{array}$ & Toys \& Games & Art & $\begin{array}{l}\text { Sand \& } \\
\text { Water }\end{array}$ & Library & Discovery & $\begin{array}{l}\text { Music \& } \\
\text { Movement }\end{array}$ & Computers & Outdoors \\
\hline Literacy & $\begin{array}{l}\text { Paper, } \\
\text { markers, tape } \\
\text { for children to } \\
\text { make signs for } \\
\text { buildings. } \\
\text { Hang charts } \\
\text { with words at } \\
\text { children's eye } \\
\text { level. }\end{array}$ & $\begin{array}{l}\text { Books \& } \\
\text { magazines } \\
\text { in house } \\
\text { corner. } \\
\text { Printed } \\
\text { receipts, } \\
\text { lists, and } \\
\text { message } \\
\text { writing } \\
\text { should be } \\
\text { included. }\end{array}$ & $\begin{array}{l}\text { Talk about colors, } \\
\text { shapes, pictures. } \\
\text { Provide matching } \\
\text { games for visual } \\
\text { discrimination }\end{array}$ & $\begin{array}{l}\text { Invite } \\
\text { children to } \\
\text { dictate } \\
\text { stories to go } \\
\text { with their } \\
\text { artwork. } \\
\text { Share books } \\
\text { about famous } \\
\text { artists. }\end{array}$ & $\begin{array}{l}\text { Add } \\
\text { literacy } \\
\text { props to the } \\
\text { sand table } \\
\text { such as } \\
\text { letter } \\
\text { molds or } \\
\text { road signs. }\end{array}$ & $\begin{array}{l}\text { Keep an } \\
\text { assortment } \\
\text { of good } \\
\text { children's } \\
\text { books on } \\
\text { display. }\end{array}$ & $\begin{array}{l}\text { Keep science } \\
\text { related books. } \\
\text { Include paper } \\
\text { and markers } \\
\text { for recording } \\
\text { observations. }\end{array}$ & $\begin{array}{l}\text { Write words } \\
\text { to a favorite } \\
\text { song on a } \\
\text { chart. Have } \\
\text { children use } \\
\text { instruments } \\
\text { for the sound } \\
\text { effects in } \\
\text { stories. }\end{array}$ & $\begin{array}{l}\text { Illustrate and } \\
\text { write the } \\
\text { steps in using } \\
\text { a computer. } \\
\text { Use a } \\
\text { drawing to } \\
\text { make a book. }\end{array}$ & $\begin{array}{l}\text { Bring colored } \\
\text { chalk and other } \\
\text { writing } \\
\text { materials } \\
\text { outside. Have } \\
\text { children } \\
\text { observe street } \\
\text { signs in the } \\
\text { neighborhood. }\end{array}$ \\
\hline Math & $\begin{array}{l}\text { Suggest } \\
\text { clean-up } \\
\text { activities that } \\
\text { involve sorting } \\
\text { by shape and } \\
\text { size. Use } \\
\text { "comparison" } \\
\text { terminology }\end{array}$ & $\begin{array}{l}\text { Add } \\
\text { telephones, } \\
\text { menus, and } \\
\text { other } \\
\text { numbered } \\
\text { items. } \\
\text { Discuss } \\
\text { prices, } \\
\text { addresses } \\
\text { etc. }\end{array}$ & $\begin{array}{l}\text { Provide } \\
\text { collections for } \\
\text { sorting, } \\
\text { classifying, and } \\
\text { graphing - and } \\
\text { patterns with } \\
\text { beads. }\end{array}$ & $\begin{array}{l}\text { Use terms of } \\
\text { comparison. } \\
\text { Provide } \\
\text { empty } \\
\text { containers of } \\
\text { various } \\
\text { shapes for } \\
\text { creating junk } \\
\text { sculptures. }\end{array}$ & $\begin{array}{l}\text { Provide } \\
\text { measuring } \\
\text { cups, } \\
\text { spoons, } \\
\text { containers } \\
\text { of various } \\
\text { sizes. Ask } \\
\text { estimation } \\
\text { questions. }\end{array}$ & $\begin{array}{l}\text { Add } \\
\text { number } \\
\text { stamps to } \\
\text { the writing } \\
\text { area. } \\
\text { Include } \\
\text { books } \\
\text { about math } \\
\text { concepts. }\end{array}$ & $\begin{array}{l}\text { Have tools on } \\
\text { hand for } \\
\text { measuring and } \\
\text { graphing. } \\
\text { Provide boxes } \\
\text { for materials } \\
\text { by size/ } \\
\text { color/shape }\end{array}$ & $\begin{array}{l}\text { Play } \\
\text { percussion } \\
\text { games } \\
\text { emphasizing } \\
\text { patterns }\end{array}$ & $\begin{array}{l}\text { Include } \\
\text { software that } \\
\text { focuses on } \\
\text { number } \\
\text { concepts, } \\
\text { patterns, } \\
\text { problem } \\
\text { solving, etc. }\end{array}$ & $\begin{array}{lr}\text { Have } & \text { children } \\
\text { look } & \text { for } \\
\text { patterns } & \text { in } \\
\text { nature } & \end{array}$ \\
\hline Science & $\begin{array}{l}\text { Talk with } \\
\text { children about } \\
\text { size, weight } \\
\text { and balance. }\end{array}$ & $\begin{array}{l}\text { Introduce } \\
\text { props such } \\
\text { as a } \\
\text { stethoscope } \\
\text { or } \\
\text { binoculars. }\end{array}$ & $\begin{array}{lr}\text { Tall } & \text { about } \\
\text { balance } & \text { and } \\
\text { weight } & \text { as } \\
\text { children use table } \\
\text { blocks. } \\
\text { classify, } \\
\text { graph } \\
\text { items. }\end{array}$ & $\begin{array}{l}\text { Describe the } \\
\text { properties of } \\
\text { materials as } \\
\text { they interact. } \\
\text { Use water } \\
\text { and brushes } \\
\text { for outdoor } \\
\text { painting. }\end{array}$ & $\begin{array}{l}\text { Make } \\
\text { bubble } \\
\text { solution } \\
\text { and } \\
\text { provide } \\
\text { different } \\
\text { kinds of } \\
\text { bubble } \\
\text { blowing } \\
\text { tools and } \\
\text { sand tools. }\end{array}$ & $\begin{array}{l}\text { Include } \\
\text { books } \\
\text { about pets, } \\
\text { plants, } \\
\text { bodies, } \\
\text { water, etc. }\end{array}$ & $\begin{array}{l}\text { Include pets } \\
\text { and plants that } \\
\text { children can } \\
\text { care for. }\end{array}$ & $\begin{array}{l}\text { Set out bottles } \\
\text { with different } \\
\text { amounts of } \\
\text { water so } \\
\text { children can } \\
\text { investigate } \\
\text { the sounds the } \\
\text { produce. }\end{array}$ & $\begin{array}{l}\text { Have children } \\
\text { observe cause } \\
\text { and effect by } \\
\text { hitting a key } \\
\text { or dragging a } \\
\text { mouse. }\end{array}$ & $\begin{array}{l}\text { Take pictures of } \\
\text { a tree the } \\
\text { children see } \\
\text { every day and } \\
\text { discuss how it } \\
\text { changes during } \\
\text { the year. }\end{array}$ \\
\hline
\end{tabular}




\begin{tabular}{|c|c|c|c|c|c|c|c|c|c|c|}
\hline $\begin{array}{l}\text { Social } \\
\text { Studies }\end{array}$ & $\begin{array}{l}\text { Include block } \\
\text { people who } \\
\text { represent a } \\
\text { range of jobs } \\
\text { and cultures }\end{array}$ & $\begin{array}{l}\text { Include } \\
\text { props } \\
\text { related to } \\
\text { different } \\
\text { kinds of } \\
\text { jobs. }\end{array}$ & $\begin{array}{l}\text { Select puzzles } \\
\text { and other items } \\
\text { that include } \\
\text { diverse } \\
\text { cultures/jobs }\end{array}$ & $\begin{array}{l}\text { Include } \\
\text { various } \\
\text { shades of } \\
\text { skin tone } \\
\text { paint, } \\
\text { crayons, and } \\
\text { markers. }\end{array}$ & $\begin{array}{l}\text { Invite } \\
\text { children to } \\
\text { describe } \\
\text { roads and } \\
\text { tunnels } \\
\text { created in } \\
\text { sand. }\end{array}$ & $\begin{array}{l}\text { Include } \\
\text { books that } \\
\text { reflect } \\
\text { diversity of } \\
\text { culture and } \\
\text { gender. }\end{array}$ & $\begin{array}{l}\text { Take nature } \\
\text { walks and post } \\
\text { the places } \\
\text { where they } \\
\text { found } \\
\text { leaves/flowers }\end{array}$ & $\begin{array}{l}\text { Show video } \\
\text { tapes of songs } \\
\text { and dances } \\
\text { from diverse } \\
\text { countries. }\end{array}$ & $\begin{array}{l}\text { Children can } \\
\text { work together } \\
\text { on software } \\
\text { related to a } \\
\text { particular } \\
\text { study topic }\end{array}$ & $\begin{array}{l}\text { Take many trips } \\
\text { in the } \\
\text { neighborhood } \\
\text { and talk about } \\
\text { what you see. }\end{array}$ \\
\hline The Arts & $\begin{array}{l}\text { Encourage } \\
\text { children to } \\
\text { build props - } \\
\text { like bridges. }\end{array}$ & $\begin{array}{l}\text { Display } \\
\text { children's } \\
\text { artwork at } \\
\text { eye-level as } \\
\text { décor. }\end{array}$ & $\begin{array}{l}\text { Include materials } \\
\text { that have } \\
\text { different art } \\
\text { elements } \\
\text { (patterns/texture) }\end{array}$ & $\begin{array}{l}\text { Provide } \\
\text { different } \\
\text { media for } \\
\text { children to } \\
\text { explore clay, } \\
\text { paint, etc. }\end{array}$ & $\begin{array}{l}\text { Create sand } \\
\text { sculptures } \\
\text { and display } \\
\text { photos of } \\
\text { these }\end{array}$ & $\begin{array}{l}\text { Talk about } \\
\text { art } \\
\text { techniques } \\
\text { used by } \\
\text { illustrators }\end{array}$ & $\begin{array}{l}\text { Provide prisms } \\
\text { and have } \\
\text { children draw } \\
\text { the designs } \\
\text { they see }\end{array}$ & $\begin{array}{l}\text { Provide a } \\
\text { variety of } \\
\text { musical } \\
\text { instruments to } \\
\text { explore }\end{array}$ & $\begin{array}{l}\text { Include } \\
\text { drawing and } \\
\text { painting } \\
\text { software }\end{array}$ & $\begin{array}{ll}\text { Bring } & \text { art } \\
\text { materials } & \\
\text { outdoors } & \text { for } \\
\text { creating } & \\
\text { pictures } & \text { and } \\
\text { sculptures } & \end{array}$ \\
\hline Technology & $\begin{array}{l}\text { Include ramps, } \\
\text { wheels and } \\
\text { pulleys. Take } \\
\text { digital photos. }\end{array}$ & $\begin{array}{l}\text { Include } \\
\text { technology } \\
\text { props such } \\
\text { as old } \\
\text { cameras, } \\
\text { keyboards. }\end{array}$ & $\begin{array}{l}\text { Add toys that } \\
\text { encourage } \\
\text { children to } \\
\text { explore how } \\
\text { things work. }\end{array}$ & $\begin{array}{l}\text { Include } \\
\text { recyclable } \\
\text { materials for } \\
\text { children to } \\
\text { create things. }\end{array}$ & $\begin{array}{l}\text { Include } \\
\text { props with } \\
\text { moving } \\
\text { parts as the } \\
\text { water table. }\end{array}$ & $\begin{array}{l}\text { Set up a } \\
\text { listening } \\
\text { area with } \\
\text { books on } \\
\text { tape. }\end{array}$ & $\begin{array}{l}\text { Introduce } \\
\text { scientific tools } \\
\text { so that they can } \\
\text { figure them } \\
\text { out. }\end{array}$ & $\begin{array}{l}\text { Electronic } \\
\text { keyboard here } \\
\text { to hear } \\
\text { different } \\
\text { sounds. }\end{array}$ & $\begin{array}{l}\text { Use computer } \\
\text { area with } \\
\text { open-ended } \\
\text { software. }\end{array}$ & $\begin{array}{l}\text { Point out } \\
\text { examples of } \\
\text { technology in } \\
\text { the outdoors. }\end{array}$ \\
\hline
\end{tabular}

Part B: Exploring Content in Interest Areas - (Dodge, Colker \& Heroman, 2002, p. 188) 
Appendix C

Sample Charting Form

Month One

Teacher/Paraprofessional

Names

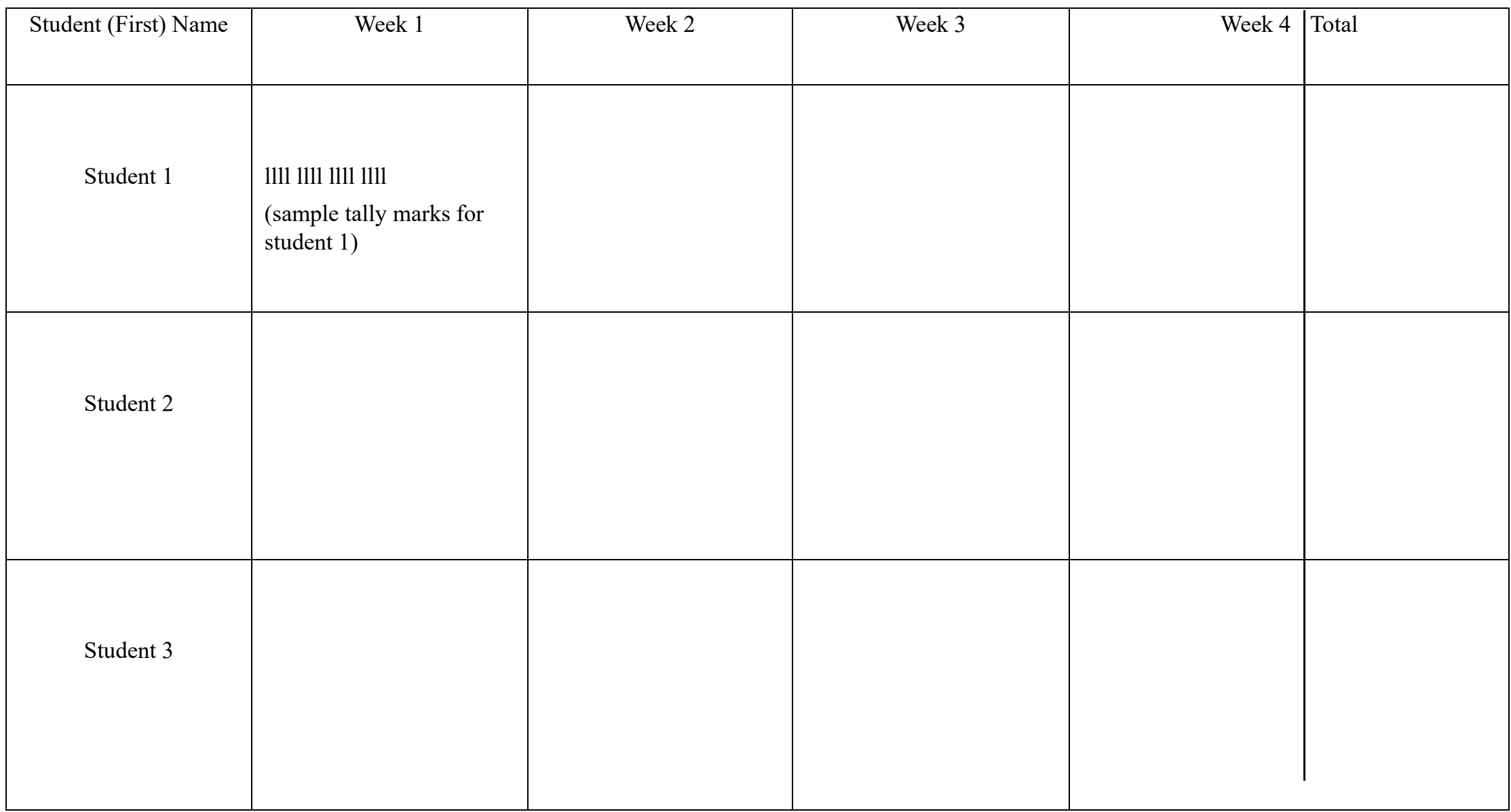


Appendix D

Questionnaires

Pre-Implementation Questionnaire

Below are some statements that may describe the feelings of teachers and paraprofessionals pre-implementation of the study.

$$
\begin{aligned}
& \qquad 1=\text { Strongly Disagree } \\
& 2=\text { Slightly Disagree } \\
& 3=\text { Neutral } \\
& 4=\text { Slightly Agree } \\
& \text { 5= Strongly Agree }
\end{aligned}
$$

a. I feel this study will be worthwhile because the students need to learn to think critically.

\section{$\begin{array}{lllll}1 & 2 & 3 & 4 & 5\end{array}$}

b. In general, I feel students are not cognitively challenged enough by teachers and paraprofessionals at Interest Area Time in the prekindergarten classroom.

\section{$\begin{array}{lllll}1 & 2 & 3 & 4 & 5\end{array}$}

c. In general, I feel teachers and paraprofessionals need to be more verbally interactive with students in Interest Areas.

\section{$\begin{array}{lllll}1 & 2 & 3 & 4 & 5\end{array}$}

d. I feel higher order questioning in Interest Areas will improve students' cognitive ability and ultimately make them more kindergarten ready.
$\begin{array}{lllll}1 & 2 & 3 & 4 & 5\end{array}$

e. I feel this implementation will be simple to carry out and not overly time consuming.

$\begin{array}{lllll}1 & 2 & 3 & 4 & 5\end{array}$ 
Additional Comments: 
Post-Implementation Questionnaire

Below are some statements that may describe the feelings of teachers and paraprofessionals post-implementation of the study.

$$
1=\text { Strongly Disagree }
$$

$2=$ Slightly Disagree

$3=$ Neutral

4= Slightly Agree

$5=$ Strongly Agree

a. I feel this study was worthwhile because the students need to learn to think critically.

\section{$\begin{array}{lllll}1 & 2 & 3 & 4 & 5\end{array}$}

b. In general, I still feel students are not cognitively challenged enough by teachers and paraprofessionals at Interest Area Time in the prekindergarten classroom.

\section{$\begin{array}{lllll}1 & 2 & 3 & 4 & 5\end{array}$}

c. I feel the teachers and paraprofessionals in this classroom are more verbally interactive with students in Interest Areas, after implementing this study.

\section{$\begin{array}{lllll}1 & 2 & 3 & 4 & 5\end{array}$}

d. I feel higher order questioning in Interest Areas has improved students' cognitive ability and ultimately made them more kindergarten ready.

\section{$\begin{array}{lllll}1 & 2 & 3 & 4 & 5\end{array}$}

e. I feel this implementation was simple to carry out and was not overly time consuming.

$\begin{array}{lllll}1 & 2 & 3 & 4 & 5\end{array}$

\section{Additional Comments:}




\section{Copyrights}

Copyright for this article is retained by the author(s), with first publication rights granted to the journal.

This is an open-access article distributed under the terms and conditions of the Creative Commons Attribution license (http://creativecommons.org/licenses/by/4.0/). 